\title{
Giant left middle fossa VII nerve schwannoma associated with amnesia
}

Figure MRI of the facial schwannoma

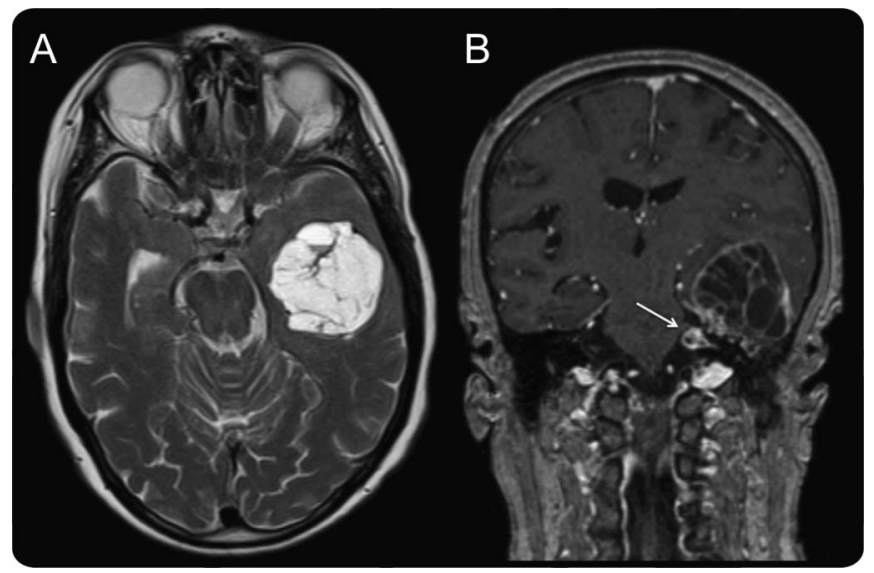

(A) Extra-axial mass located in the left middle fossa of multicystic appearance. The lesion of well-defined limits compresses the neighboring brain parenchyma and has no surrounding edema. (B) There is additional involvement of the internal auditory canal invading the left pontocerebellar cistern (arrow).

The facial nerve is the third most frequent location of intracranial schwannomas, with facial paresis the most common sign. ${ }^{1,2}$ A 77-year-old woman presented with amnesia; the Mini-Mental State Examination score was 26, with normal cranial nerve function. A giant multicystic VII nerve schwannoma was identified in the left middle fossa, with components of the tumor in the temporal bone facial canal, geniculate ganglion, and internal auditory canal (figure). Compression of the hippocampus may have accounted for the clinical presentation. The middle fossa component of the tumor was resected for mass effect relief, with iatrogenic facial palsy.

André Cunha, MD, Daniela Seixas, MD, PhD, Lino Mascarenhas, MD, Mário Resende, MD, Antónia Furtado, MD, António Rui Figueiredo Ribeiro, MD

From the Departments of Neuroradiology (A.C., D.S., A.R.F.R.), Neurosurgery (L.M., M.R.), and Anatomical \& Cellular Pathology (A.F.), C. Hospitalar Vila Nova Gaia/Espinho and Faculty of Medicine of Porto University (D.S.), Portugal.

Author contributions: Dr. André Cunha: study concept and design. Prof. Dr. Daniela Seixas: critical revision of the manuscript for important intellectual content. Dr. Lino Mascarenhas: supervision of clinical details. Dr. Mário Resende: acquisition of clinical data. Dr. Antónia Furtado: analysis and interpretation of pathologic data. Dr. António Rui Figueiredo Ribeiro: acquisition and supervision of image data. Study funding: No targeted funding reported.

Disclosure: The authors report no disclosures relevant to the manuscript. Go to Neurology.org for full disclosures.

Correspondence to Dr. Cunha: andrecunha86@hotmail.com

1. Veillon F, Taboada LR, Eid MA, et al. Pathology of the facial nerve. Neuroimaging Clin N Am 2008;18:309-320.

2. Lassaletta L, Roda JM, Frutos R, Patrón M, Gavilán J. Facial nerve schwannoma of the cerebellopontine angle: a diagnostic challenge. Skull Base 2002;12:203-207. 


\section{Neurology}

\section{Giant left middle fossa VII nerve schwannoma associated with amnesia André Cunha, Daniela Seixas, Lino Mascarenhas, et al. Neurology 2013;81;602 \\ DOI 10.1212/WNL.0b013e31829e6eec}

\section{This information is current as of August 5, 2013}

\section{Updated Information \& Services}

References

Subspecialty Collections

Permissions \& Licensing

Reprints including high resolution figures, can be found at: http://n.neurology.org/content/81/6/602.full

This article cites 2 articles, 0 of which you can access for free at: http://n.neurology.org/content/81/6/602.full\#ref-list-1

This article, along with others on similar topics, appears in the following collection(s):

MRI

http://n.neurology.org/cgi/collection/mri

Nerve tumor

http://n.neurology.org/cgi/collection/nerve_tumor

Information about reproducing this article in parts (figures,tables) or in its entirety can be found online at:

http://www.neurology.org/about/about_the_journal\#permissions

Information about ordering reprints can be found online:

http://n.neurology.org/subscribers/advertise

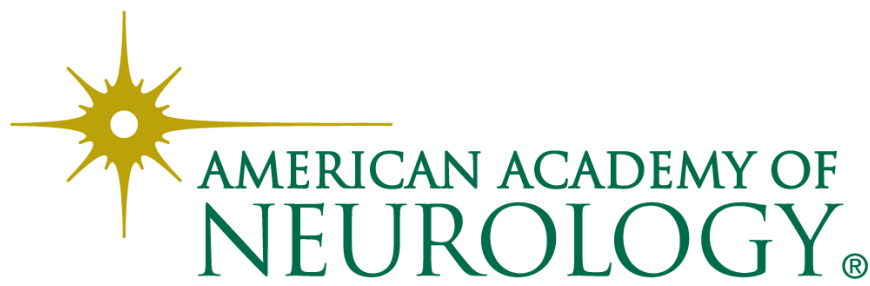

